\title{
Solar Resource Assessment for Sri Lanka and Maldives
}
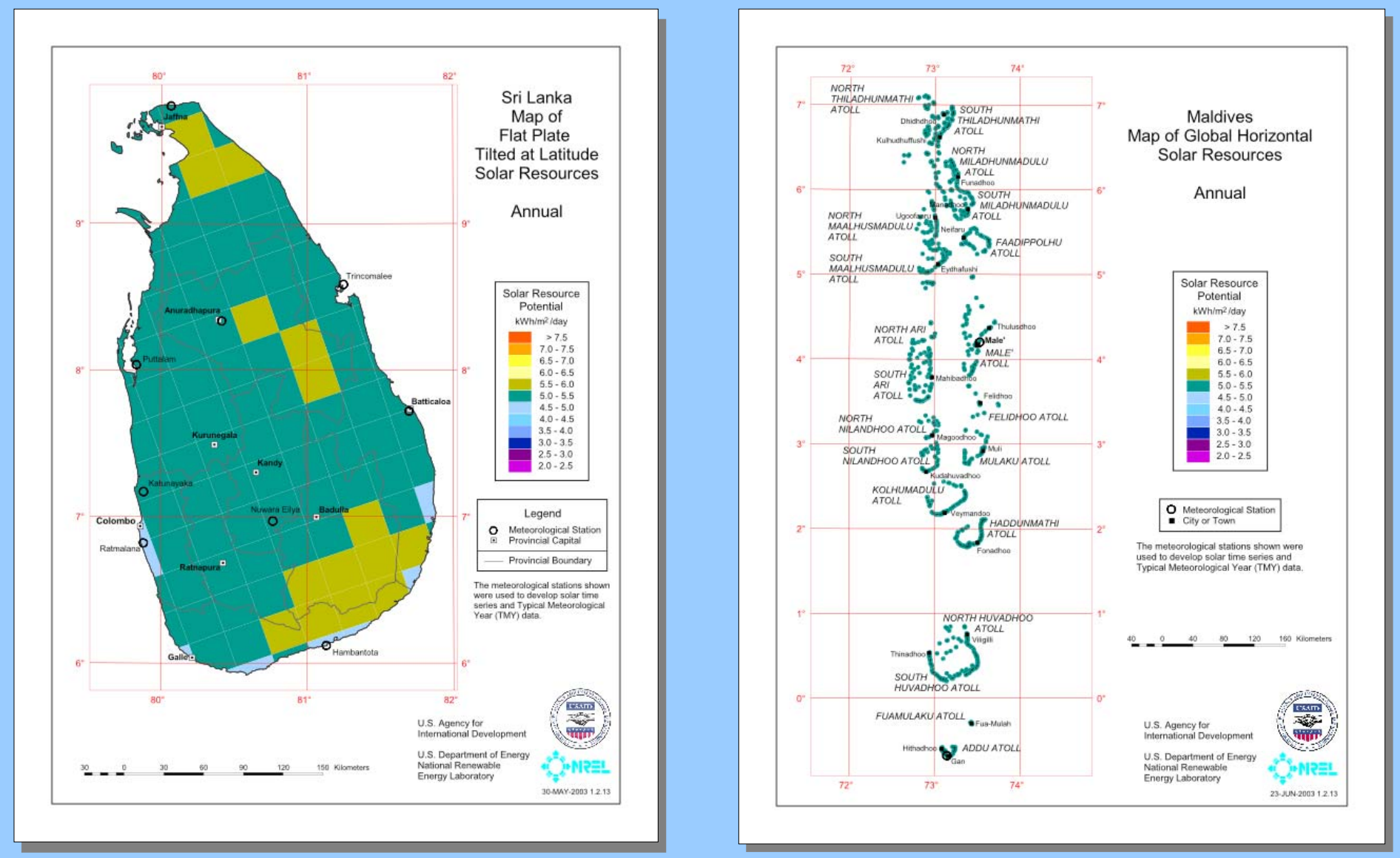

\section{Prepared by:}

Dave Renné, Ray George, Bill Marion and Donna Heimiller (NREL)

Chris Gueymard (Solar Consulting Services) 
August 2003 • NREL/TP-710-34645

\section{Solar Resource Assessment for Sri Lanka and Maldives}

Prepared by:

Dave Renné, Ray George, Bill Marion and Donna Heimiller

National Renewable Energy Laboratory

Chris Gueymard Solar Consulting Services

Prepared under Task No. WF7C.0202

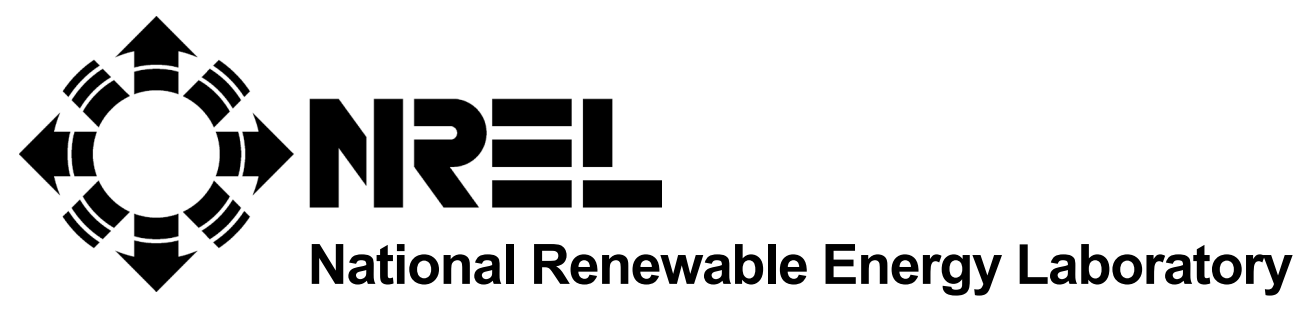

1617 Cole Boulevard

Golden, Colorado 80401-3393

NREL is a U.S. Department of Energy Laboratory

Operated by Midwest Research Institute $\bullet$ Battelle $\bullet$ Bechtel

Contract No. DE-AC36-99-G010337 


\section{NOTICE}

This report was prepared as an account of work sponsored by an agency of the United States government. Neither the United States government nor any agency thereof, nor any of their employees, makes any warranty, express or implied, or assumes any legal liability or responsibility for the accuracy, completeness, or usefulness of any information, apparatus, product, or process disclosed, or represents that its use would not infringe privately owned rights. Reference herein to any specific commercial product, process, or service by trade name, trademark, manufacturer, or otherwise does not necessarily constitute or imply its endorsement, recommendation, or favoring by the United States government or any agency thereof. The views and opinions of authors expressed herein do not necessarily state or reflect those of the United States government or any agency thereof.

Available electronically at http://www.osti.gov/bridge

Available for a processing fee to U.S. Department of Energy

and its contractors, in paper, from:

U.S. Department of Energy

Office of Scientific and Technical Information

P.O. Box 62

Oak Ridge, TN 37831-0062

phone: 865.576.8401

fax: 865.576 .5728

email: reports@adonis.osti.gov

Available for sale to the public, in paper, from:

U.S. Department of Commerce

National Technical Information Service

5285 Port Royal Road

Springfield, VA 22161

phone: 800.553.6847

fax: 703.605.6900

email: orders@ntis.fedworld.gov

online ordering: http://www.ntis.gov/ordering.htm 


\title{
Solar Resource AsSessment for Sri LANKa AND The Maldives
}

\author{
Prepared by: \\ Dave Renné, Ray George, Bill Marion, and Donna Heimiller (NREL) \\ Chris Gueymard (Solar Consulting Services)
}

\section{Introduction and Background}

The countries of Sri Lanka and the Republic of the Maldives lie within the equatorial belt, a region where substantial solar energy resources exist throughout much of the year in adequate quantities for many applications, including solar water heating, solar electricity, and desalination. Many applications of solar energy are currently in use for meeting remote electrical loads throughout much of the non-electrified regions of Sri Lanka. The potential exists for significant expansion of the use of this renewable energy. Solar photovoltaic technology is currently cost-effective for meeting remote electrical loads and for providing a distributed source of electricity without the requirement of adding extensive grid infrastructure or putting a burden on the existing grid. In the Maldives, solar electricity operating in a hybrid configuration with existing diesel technology, or perhaps replacing diesel altogether with sufficient battery storage and additional hybridization with wind energy technologies, can offset the need for costly imported fossil fuels, thereby reducing local pollution levels. Nevertheless, a good, quantitative knowledge of the distribution and extent of solar resources in Sri Lanka and the Maldives is essential in order to make appropriate decisions on the application of solar technologies, to properly size the systems being designed to meet loads, and to attract further investment in these technologies.

The extent of solar resources in Sri Lanka has been estimated in the past based on a study of the daily total direct sunshine hours recorded at a number of weather and agricultural stations throughout the country. These data have been applied to the well-known Angstrom relationship in order to obtain an estimate of the distribution of monthly average daily total solar resources at these stations $[1,2]$. The results of this study shows that the distribution of annual solar resources varies from $15-20 \mathrm{MJ} / \mathrm{m} 2 /$ day (4.2 to 5.6 $\mathrm{kWh} / \mathrm{m} 2 /$ day) across the country, with the lowest values occurring in the hill country in the south-central region. The results also showed that the country does not experience sharp seasonal changes in solar resources. Besides the inherent errors in the empirical approach using the Angstrom equation, the other limitations in these estimates are that they apply only to the 26 observation stations, and that they are only suitable for global horizontal solar resource estimates. These studies do not include the other solar resource components (Direct Normal Irradiance, or DNI, and diffuse radiation) that are required for other types of solar applications, such as concentrating solar power and building daylighting.

This study is an effort to improve on these estimates in two ways: 1) to apply a gridded cloud cover database at a $40-\mathrm{km}$ resolution to produce updated monthly average daily total 
estimates of all solar resources (global horizontal, DNI, and diffuse) for the country, and 2) to input hourly or three-hourly cloud cover observations made at nine weather stations in Sri Lanka and two in the Maldives into a solar model that produces estimates of hourly solar radiation values of the direct normal, global, and diffuse resource covering the length of the observational period. Details and results of these studies are summarized in this report.

\section{Fundamentals of the Solar Resource Estimation Techniques}

A complete solar resource assessment includes a depiction of the variation of the solar resource across a region as well as the manner in which solar radiation varies on an hourly basis at specific points. Thus, two types of analyses are used here: one to generate time series analyses for specific weather observations stations in Sri Lanka and the Maldives, and the other to depict the climatological distribution of solar resources by season and annually across the two countries. The models used for each approach are described below, and the data inputs to these models are described in Section 3. Further information on the models can be found in the appropriate references.

\subsection{METSTAT Model for Solar Time Series Analysis}

The METSTAT solar radiation model [3] was developed using quality assessed solar radiation and other meteorological data collected from 1978 to 1980 at 29 U.S. National Weather service sites. The model calculates hourly values of global horizontal radiation, DNI, and diffuse horizontal radiation. Input parameters to the model include total and opaque cloud cover, aerosol optical depth, precipitable water vapor, ozone, surface albedo, snow depth, days-since-last-snowfall, atmospheric pressure, and present weather. The model uses deterministic algorithms to calculate accurate monthly means for each hour and statistical algorithms to simulate the statistical and stochastic characteristics of measured multiyear data sets.

The statistical algorithms randomly vary the selected input parameters of opaque cloud cover and aerosol optical depth. This simulates the effects of random hour-to-hour changes in cloud position relative to the sun and day-to-day changes in aerosol optical depth and provides estimates of hourly solar radiation with representative statistical characteristics of measured data. Without the statistical algorithms, the model would calculate the same solar radiation values whenever the input variables and the solar geometry were the same.

\subsection{Climatological Solar Radiation (CSR) Model for Solar Resource Mapping}

The annual and seasonal climatological solar radiation maps for Sri Lanka and the Maldives were developed using the 40-km resolution gridded cloud cover data (Real-Time Nephanalysis) provided by the National Climatic Data Center as input to NREL's Climatological Solar Radiation (CSR) model. The CSR model incorporates most of the deterministic algorithms of the parametric METSTAT model described above, using inputs of monthly mean values of total and opaque cloud cover, aerosol optical depth, precipitable water vapor, atmospheric pressure, ozone, and surface albedo. Both models first calculate 
unit less transmittance values for the direct beam and diffuse sky solar radiation elements for each atmospheric parameter that absorbs or scatters radiation. The transmittance values are then multiplied by appropriate extraterrestrial (top-of-the-atmosphere) solar radiation values to yield surface solar radiation values in watt-hours per square meter $\left(\mathrm{Wh} / \mathrm{m}^{2}\right)$.

The CSR model was structured in a manner that would inherently incorporate the expected effects of day length and declination angle. This was accomplished by calculating solar radiation energy for each five-minute period, from sunrise to sunset, during a "typical" day of each month. A "typical" day represents the day of each month for which the daily-total extraterrestrial radiation (ETR) most nearly equals the monthly mean daily-total ETR. In this way, the monthly mean daily-totals of direct normal, diffuse horizontal, and global horizontal solar radiation are obtained for each month of the year. The model then summarizes the 5-minute values to obtain a daily-total value.

For each month, the CSR model calculations proceed through the following steps:

Step 1 - Solar Geometry

Starting at midnight, the date and the latitude and longitude of a cell are used to calculate the solar elevation. These calculations are repeated every 5 minutes until the sun comes up, at which time the algorithms to calculate solar radiation are implemented and used until the sun sets. Logic statements handle the high latitude situations for those periods when the sun never comes up or when it never sets.

Step 2 - Direct Beam \& Diffuse Transmittances

Direct beam transmittance algorithms include the effects of Rayleigh scattering, ozone absorption, uniformly mixed gas absorption, water vapor absorption, aerosol absorption and scattering, opaque cloud absorption, and translucent cloud absorption. Diffuse sky transmittance algorithms include contributions from Rayleigh scattering, aerosol scattering, opaque cloud scattering, translucent cloud scattering, and multiple ground-toatmosphere/cloud reflectances.

Step 3 - Combining Transmittances

The algorithm to combine direct beam and diffuse transmittances is,

$$
\mathrm{Kt}=\mathrm{Kn}+\mathrm{Kd}
$$

where $\mathrm{Kt}, \mathrm{Kn}$, and $\mathrm{Kd}$ are transmittances for global horizontal, direct normal, and diffuse horizontal solar radiation respectively. Corrections are made for sunrise and sunset periods shorter than 5 minutes in length.

\section{Step 4 - Calculating Solar Irradiance}

The solar radiation intensity for each 5-minute period is accomplished by multiplying the sum of the transmittances by ETR and ETRN (extraterrestrial solar radiation on a horizontal surface and extraterrestrial radiation normal to the sun). 


\section{Step 5 - Calculating Daily-Total Energy}

For the final step, the daily-total solar radiation energy in Watt-hours $/ \mathrm{m}^{2}$ is calculated by summing 5-minute values and dividing by 12 .

The CSR model is dependent on the availability of various climatological input data sets. The most important of these is total and opaque cloud cover. A gridded climatological cloud cover data, obtained from the U.S. National Climatic Data Center (NCDC), is used as model input, and is described in Section 3.2. After clouds, the next most important data input to the CSR model (as well as the METSTAT model) is atmospheric aerosol optical depth, or turbidity. Airborne aerosols act to scatter and absorb the incoming solar irradiance, and under clear sky conditions this phenomenon can have important influences on the actual amount of solar radiation reaching the ground, particularly for the direct beam. A discussion on how aerosol optical depth data is derived for input to the CSR and METSTAT models is given in Section 3.3.

CSR model results have been compared with monthly mean daily-totals extracted from the National Solar Radiation Data Base (NSRDB) for 213 sites in the contiguous United States. In general, these monthly mean bias differences are less than $3 \%$ of typical monthly mean daily-totals and the RMS differences are less than half of typical interannual variations (standard deviations of monthly means).

\section{Model Input Data}

\subsection{DATSAV2 Surface Meteorological Data}

DATSAV2 data consist of surface weather observations taken around the world. The primary reason for these weather observations is to support forecasting and aviation; consequently, most stations are located at airports. The observations are sent across the Global Telecommunications System (GTS), from which they are collected and decoded by the Air Force Global Weather Center (AFGWC) for forecasting purposes. AFGWC then sends the observations to the U.S. Air Force Technical Applications Center (now the Air Force Combat Climatology Center) for further decoding, quality control, and archiving [4].

DATSAV2 data are distributed by the NCDC [5] and are available as soon as three weeks after the data month. The period of record varies by station, with most beginning in 1973, but some stations have a limited amount of data as far back as the 1930s. DATSAV2 data exist for about 20,000 stations, of which 10,000 are currently active.

Most of the active stations take and transmit observations every three hours. However, some take observations every hour, while others take less frequent observations, such as every six hours or more. Some stations may not take observations during the night. Industrialized regions have more stations and observations.

DATSAV2 observations useful for solar radiation modeling include: total sky cover, fraction of sky dome covered by low clouds, low cloud type, middle cloud type, high cloud 
type, and ceiling. Other important parameters include visibility, dry bulb temperature, dew point temperature, sea level pressure, wind speed, wind direction, and present weather.

Figure 1 provides a topographic map of Sri Lanka showing the location of DATSAV2 stations used for generating time series data from the METSTAT model. Information on the selected stations is provided in Section 4.1.

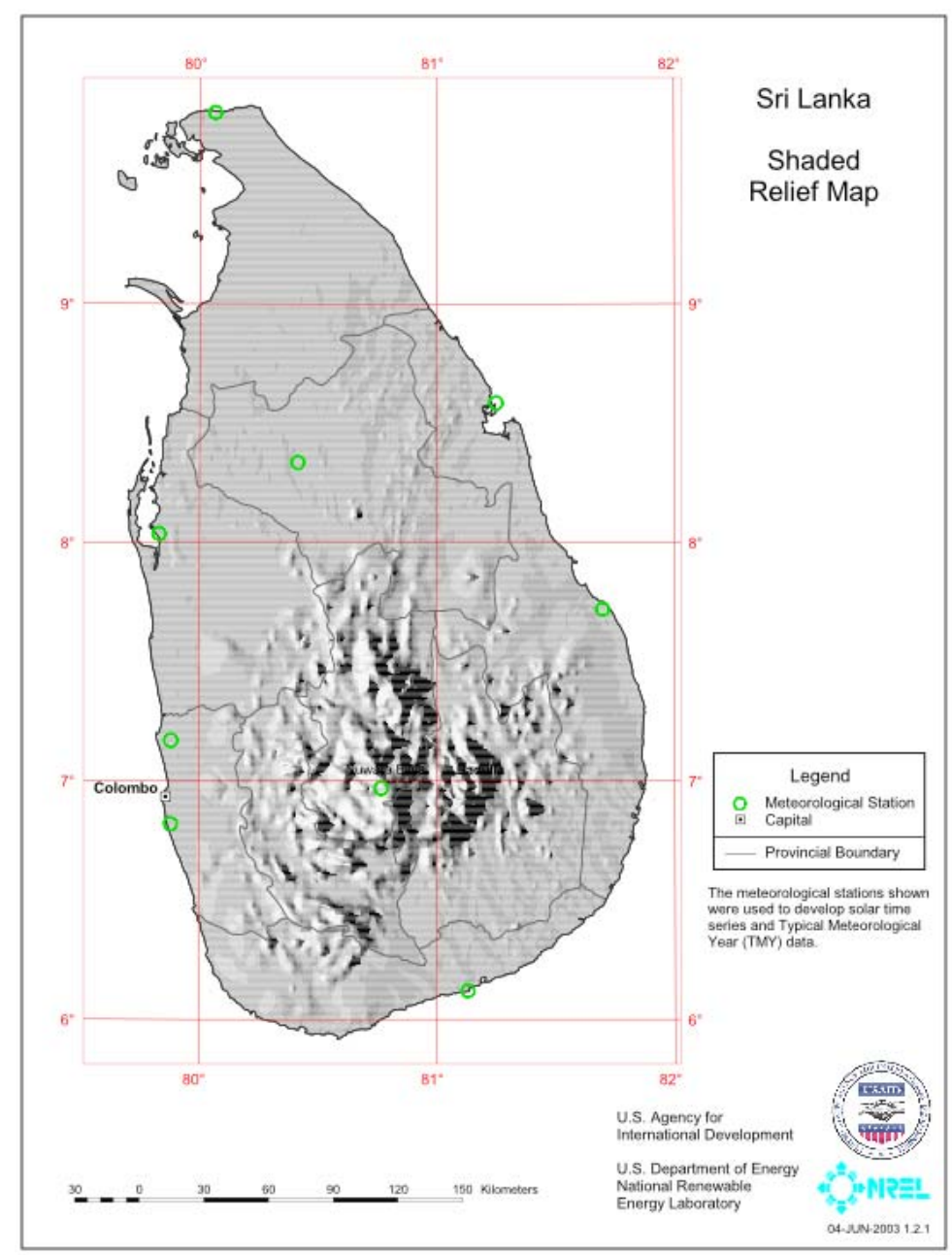

Figure 1: Topography of Sri Lanka, and location of DATSAV2 weather service stations where cloud cover observations exist that are used as input to the METSTAT model for solar radiation time series calculations.

\subsection{Real Time Nephanalysis (RTNEPH) Cloud Database}

Cloud cover input data to the CSR model are derived from a histogram database formed from a 7-year period (1985 - 1991) of 3-hourly data derived from the Real Time Nephanalysis (RTNEPH). The RTNEPH originates at the Air Force Global Weather Center (AFGWC) at Offutt AFB, Nebraska. On August 1, 1983, AFGWC started a global cloud analysis project that produces cloud information every 3 hours for grid points 
separated by a nominal $40 \mathrm{~km}$. These analyses use all available information, including surface observations, upper air (radiosonde) data, and polar orbiting satellite data to produce cloud data for polar stereographic projections of the Northern and Southern hemispheres. Although not as reliable as hourly surface observations, the $40 \mathrm{~km}$ resolution makes these data ideal for medium resolution climatological solar resource analyses anywhere in the world.

The 7-year histogram includes the number of occurrences of low, middle, high, and total cloud amounts in increments of 5\% for sky cover amounts from $0 \%$ to $100 \%$ for each month and each 3-hour observation time. The histograms of total sky cover amounts for hours between sunrise and sunset are used to determine monthly mean total cloud cover during daylight hours. Opaque cloud cover amounts are estimated from analyses of the low, middle, and high cloud amounts.

\subsection{Aerosol Optical Depth (AOD) Data}

Aerosol optical depth (AOD) has an important effect on surface radiation, especially on the DNI and diffuse sky radiation. Aerosols (dust, smoke, pollen, liquid droplets) primarily act as scatterers that reduce direct beam radiation and increase diffuse radiation. Because most of the radiation scattered out of the beam becomes diffuse sky radiation, the effect of aerosols on global horizontal radiation is relatively small. Typically, if aerosols reduce the direct beam radiation by as much as $20 \%$, the global horizontal radiation may be reduced by as little as 5\%. The CSR model requires monthly averages for all the input parameters including AOD. NREL creates these monthly averages by first estimating an annual average AOD and then using a seasonal function to modify the annual average for each month. The METSTAT model uses the same AOD information for each surface station location, and calculates a daily mean value of AOD based on the seasonal values. AOD is determined for each surface station location, and a daily mean value of AOD is calculated based on the seasonal values. For humid tropical areas such as Sri Lanka and the Maldives, the solar resource is not highly sensitive to AOD, as the DNI resource is fairly low compared to the resource in desert areas.

For this study of Sri Lanka and the Maldives, several different aerosol data sources were used. The seasonal function of AOD were estimated using surface measured sun photometry data from Male and Kashidoo in the Maldive Islands. This profile, as shown in Figure 2, shows two peaks, one in March and the other in July, with decreased AOD in the fall after the summer monsoon season is over. This profile for Sri Lanka was then adjusted by reducing the magnitude of the March peak, based on data from the Indian Ocean Experiment (INDOEX) that shows higher AOD values for spring west of India than in the Bay of Bengal (c.f. references [6], [7], [8], [9]).

An annual average mean AOD value of 0.165 was chosen for Male, Republic of the Maldives, based on AERONET sun photometer data [10]. A value of 0.135 was chosen for Gan Island, at the southern end of the Maldives. Annual average AOD for the rest of the

Maldives was then varied linearly with latitude, up to a maximum of 0.184 at the northernmost location. 
For Sri Lanka, a second data source was also used, which applies only to ocean and coastal areas. This is the AOD data measured from space in a worldwide data set known as "TD9614 Aerosol Analyses". The TD-9614 data sets are derived from the National Oceanic and Atmospheric Administration's (NOAA's) Advanced Very High Resolution Radiometer (AVHRR) satellite data. The data have been previously processed into a $1^{0} \times 1^{0}$ (approximately $100 \mathrm{~km}$ to a side) grid and made available over the World Wide Web [11]. These data are for two years only (July 1989 to June 1991). Adjustments were made for increased AOD observed over the last decade, as shown by comparing TD-9614 data with recent (December 1998 - December 2001) Aeronet sun photometer data for the Maldives. An examination of scientific literature and maps suggested that this increase of about $10 \%$ should also apply to Sri Lanka [12].

The AOD pattern in Sri Lanka we used includes a maximum of 0.25 in the Colombo metropolitan area. AOD in southern Sri Lanka is about 0.16 with an increasing gradient toward the north, such that the AOD at the northern end of Sri Lanka is about 0.21. An adjustment for ground elevation at all grid cells and DATSAV2 stations was also made. This adjustment has the effect of decreasing the AOD by $50 \%$ at elevations of 2000 meters above sea level. All locations in Sri Lanka used the seasonal profile shown in Figure 2.

\section{Sri Lanka - Maldives Seasonal Aerosol Pattern}

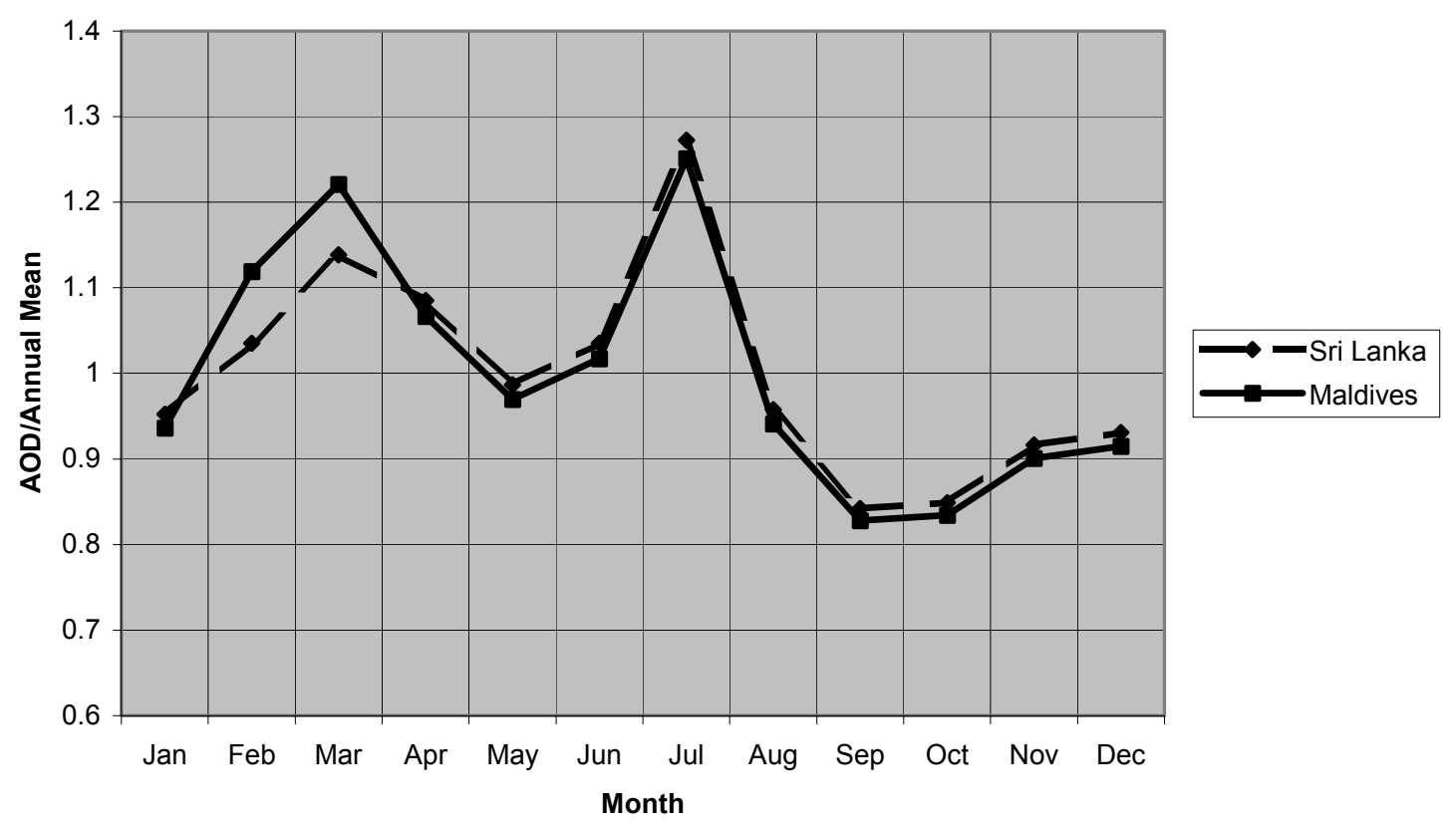

Figure 2: Seasonal patterns of Aerosol Optical Depth (AOD) for Sri Lanka and the Maldives. Value is the ratio of monthly AOD to the chosen annual AOD value. 


\subsection{Precipitable Water and Other Data Inputs}

Monthly mean precipitable water vapor data on a global 1-degree grid were obtained from the NASA Water Vapor Project (NVAP) dataset, which is described in ref. [13]. This data set was prepared from high quality radiosonde (upper air) data combined with data from the TIROS Operational Vertical Sounder (TOVS) and the Special Sensor Microwave/Imager (SSM/I) on the TIROS satellite. These data cover the period from 1988 to 1997. The NVAP data set has undergone extensive quality control and provides uniform worldwide coverage. Because water vapor absorbs (rather than scatters) solar energy, it affects all three elements (DNI, diffuse and global) by similar amounts.

Atmospheric pressure data were calculated from 5 -minute $(9 \mathrm{~km}$ grid) elevation data that are available for the entire world [14]. Atmospheric pressure is an input to the algorithms that calculate the Rayleigh scattering and quantum absorption processes associated with uniformly mixed atmospheric gases (nitrogen, oxygen, carbon dioxide, etc.). The absorption of oxygen and carbon dioxide has a rather minor effect on surface radiation but the effect of Rayleigh scattering is exceeded only by the effects of aerosols and clouds.

Ozone data for the world were obtained from the Total Ozone Mapping Spectrometer, available on a CD-ROM produced by NOAA [15]. The absorption of solar energy by ozone provides a vital shield to limit the intensity of ultra violet (UV) radiation, which is damaging to both plants and animals. However, UV radiation comprises only a small percentage of the total radiation from the sun. Hence, the effect of ozone on broadband solar radiation is not of great importance.

Worldwide surface albedo data are available from a number of sources, including the Canadian Center for Remote Sensing (CCRS) [16]. The satellite derived 2.5 degree CCRS data were used to estimate monthly mean surface albedo for Sri Lanka, over the land. These data were adjusted to account for the fact that the 2.5-degree cells included some water that has a lower albedo than the land. In fact, only one monthly albedo profile was obtained for all of Sri Lanka using this method. The same data were also used for all model cells and METSTAT model runs in the Maldives. Surface albedo affects multiple scattering of solar radiation between the surface of the earth and the atmosphere (especially clouds). This affects the diffuse and global elements of solar radiation, but has no effect on the DNI.

The various model input data have spatial resolutions varying from $9 \mathrm{~km}$ (elevation/pressure) to $550 \mathrm{~km}$ (AOD). Because cloud cover plays a dominate role in determining solar radiation at the earth's surface, the polar projection $40 \mathrm{~km}$ grid of the RTNEPH data base was selected for both the input and output grids of the CSR model. Therefore, all of the non-cloud cover data inputs were resampled such that input values for all variables were available for each of the RTNEPH $40 \mathrm{~km}$ cells. The resampling process used standard interpolation and geostatistical procedures including weighted averaging of input grid values within a prescribed distance of the cell of interest. Maps prepared for each of the resampled data input grids were examined as part of the overall quality control procedures. 


\section{Typical Meteorological Year Data for Selected Stations in Sri Lanka and the Maldives}

Multi-year sets of hourly solar radiation and meteorological data were derived for those DATSAV2 stations where the record and data quality were sufficient. The METSTAT model, based on the methodology described in ref. [17], was then run on those stations to produce hourly time series of solar resource data. From each multi-year data set, a Typical Meteorological Year (TMY) was derived using procedures described in ref. [18].

A TMY is a data set of hourly values of solar radiation and meteorological elements for a 1 -year period. It consists of months selected from individual years and concatenated to form a complete year. The intended use is for computer simulations of solar energy conversion systems and building systems. Because of the selection criteria, these TMYs are not appropriate for simulations of wind energy conversion systems.

A TMY provides a standard for hourly data for solar radiation and other meteorological elements that permit performance comparisons of system types and configurations for one or more locations. A TMY is not necessarily a good indicator of conditions over the next year, or even the next 5 years. Rather, it represents conditions judged to be typical over a long period of time, such as 30 years. Because they represent typical rather than extreme conditions, they are not suited for designing systems and their components to meet the worst-case conditions occurring at a location.

Multi-year data sets and TMYs were developed for the DATSAV2 locations shown in Table 4-1. The city name and country follow DATSAV2 convention.

Table 4-1. Sri Lanka and Maldives Station Locations.

\begin{tabular}{|c|c|c|c|c|c|c|}
\hline WMO No. & City & Country & $\begin{array}{l}\text { Time } \\
\text { Zone }\end{array}$ & $\begin{array}{c}\text { Latitude } \\
\text { (deg min) }\end{array}$ & $\begin{array}{l}\text { Longitude } \\
\text { (deg min) }\end{array}$ & $\begin{array}{c}\text { Elevation } \\
(\mathrm{m})\end{array}$ \\
\hline 434000 & KANKESANTURAI_(AFB) & SB & +6 & N 948 & E 8004 & 10 \\
\hline 434180 & TRINCOMALEE_(AFB) & SB & +6 & N 835 & E 8115 & 7 \\
\hline 434210 & ANURADHAPURA_(AFB) & SB & +6 & N 820 & E 8025 & 89 \\
\hline 434240 & PUTTALAM & SB & +6 & N 802 & E 7950 & 2 \\
\hline 434360 & BATTICALOA_(AFB) & SB & +6 & N 743 & E 8142 & 12 \\
\hline 434500 & COLOMBO/KATUNAYAKE & SB & +6 & N 710 & E 7953 & 8 \\
\hline 434670 & COLOMBO/RATMALANA & $\mathrm{SB}$ & +6 & N 649 & E 7953 & 5 \\
\hline 434730 & NUWARA_ELIYA & SB & +6 & N 658 & E 8046 & 1880 \\
\hline 434970 & HAMBANTOTA & SB & +6 & N 607 & E 8108 & 20 \\
\hline 435550 & MALE_INTL/HULULE_IS & MV & +5 & N 412 & E 7332 & 2 \\
\hline 435990 & GAN_ISLAND & MV & +5 & S 041 & E 7309 & 2 \\
\hline
\end{tabular}




\section{Sri Lanka Solar Climate}

Figure 3 shows the distribution of annual solar resources for a fixed collector oriented at latitude tilt and for DNI (e.g. 2-axis concentrating collectors) in Sri Lanka.

The CSR model provides monthly average daily total solar radiation estimates for the seven-year period 1985-1991. The seasonal climate is depicted for four major regimes: the Northeast Monsoon (December through February), the Southwest Monsoon (May through September), and two inter-Monsoonal periods (March through April and October through November). Figure 4 shows the solar resource for a fixed flat plate collector oriented at latitude tilt for the Northeast and the Southwest Monsoons in Sri Lanka, and Figure 5 shows the same solar resource value for the two inter-Monsoonal periods. Figure 6 shows the DNI resource for the Northeast and the Southwest monsoons, while Figure 7 shows the DNI resource for the two inter-monsoonal periods.
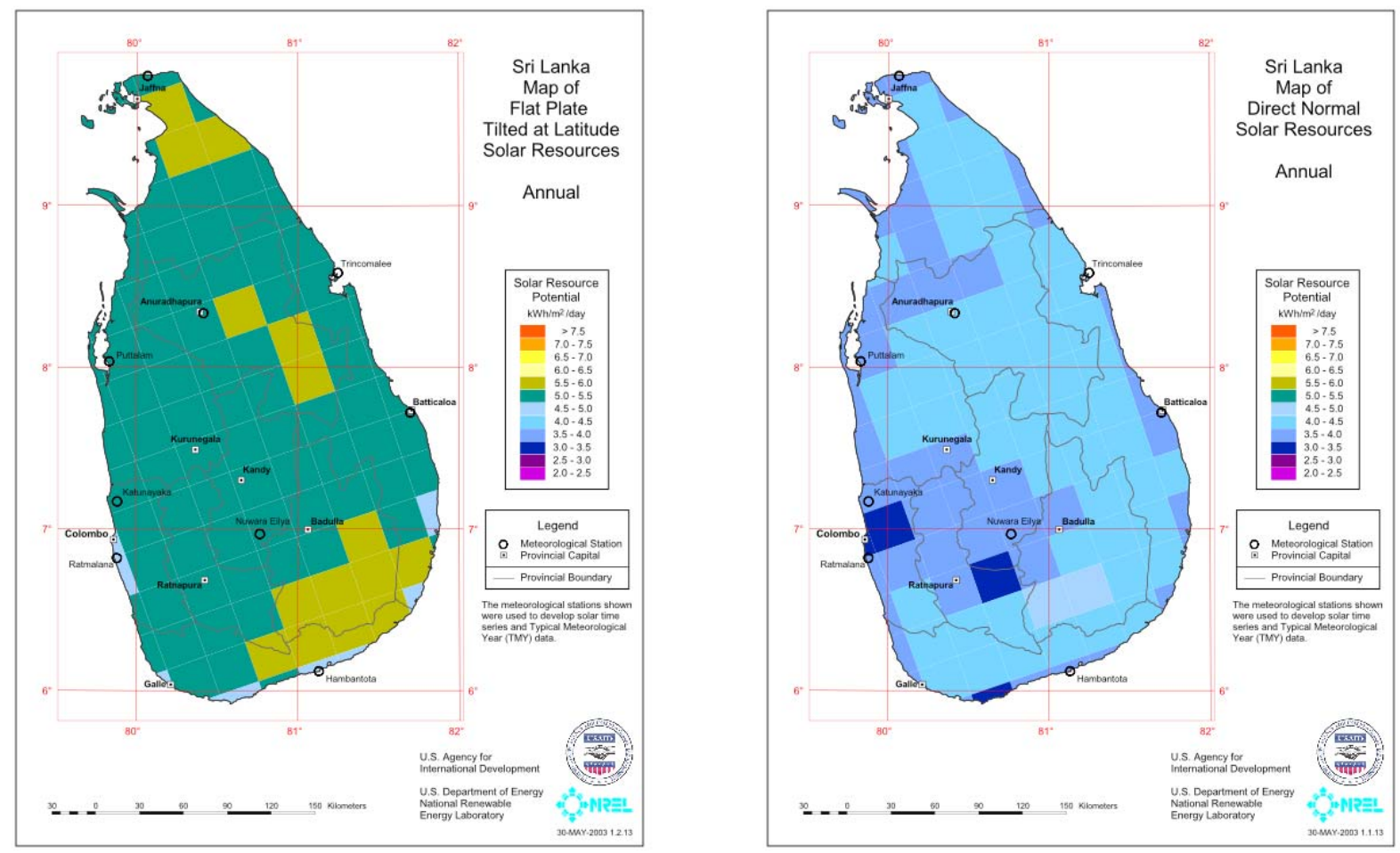

Figure 3:

Annual average daily total solar resources for fixed flat plate collector tilted at latitude (left) and for DNI (right). 

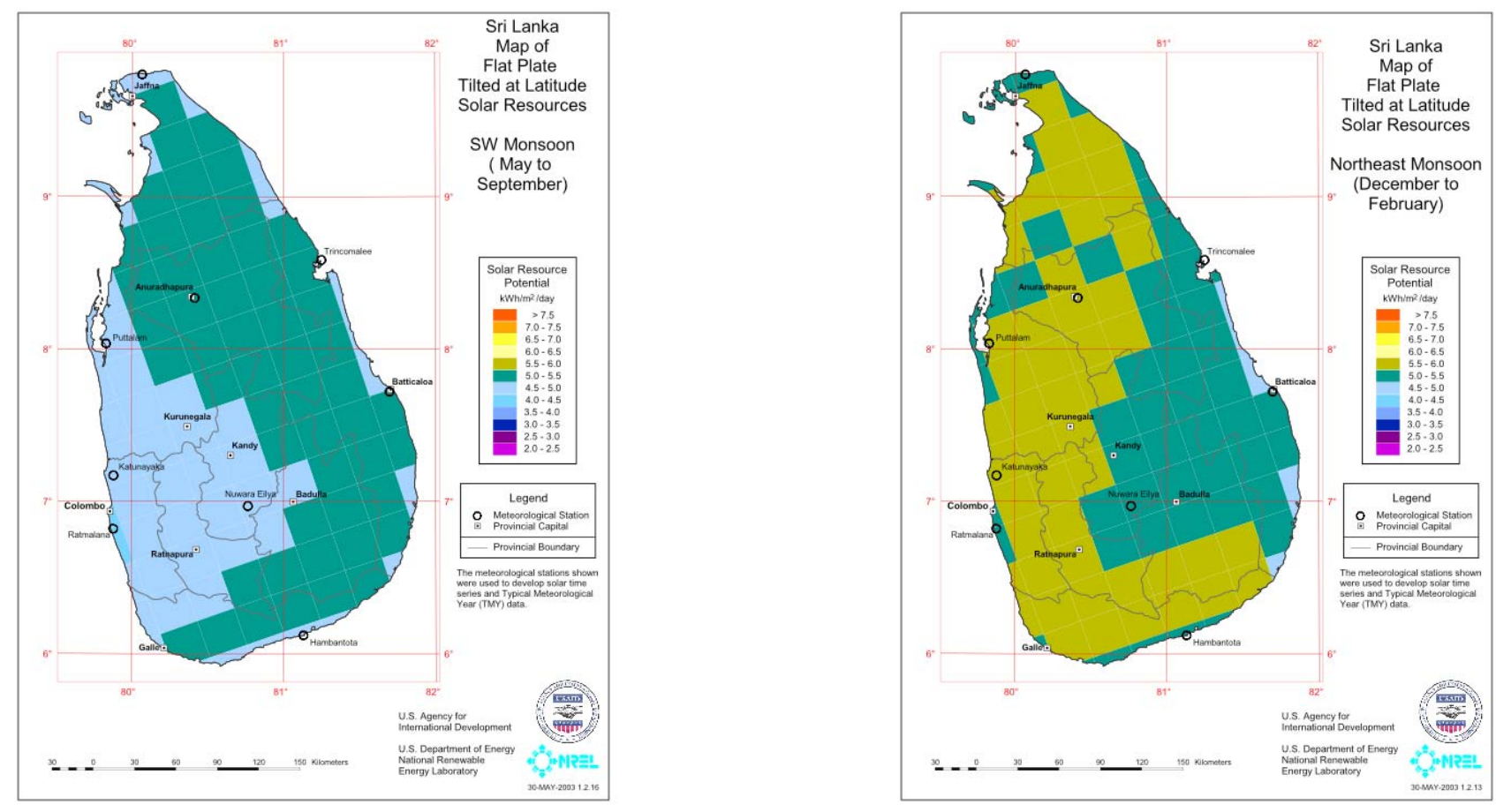

Figure 4:

Solar resources on a fixed flat-plate collector oriented at latitude tilt for the Southwest Monsoon (left) and the Northeast Monsoon (right).
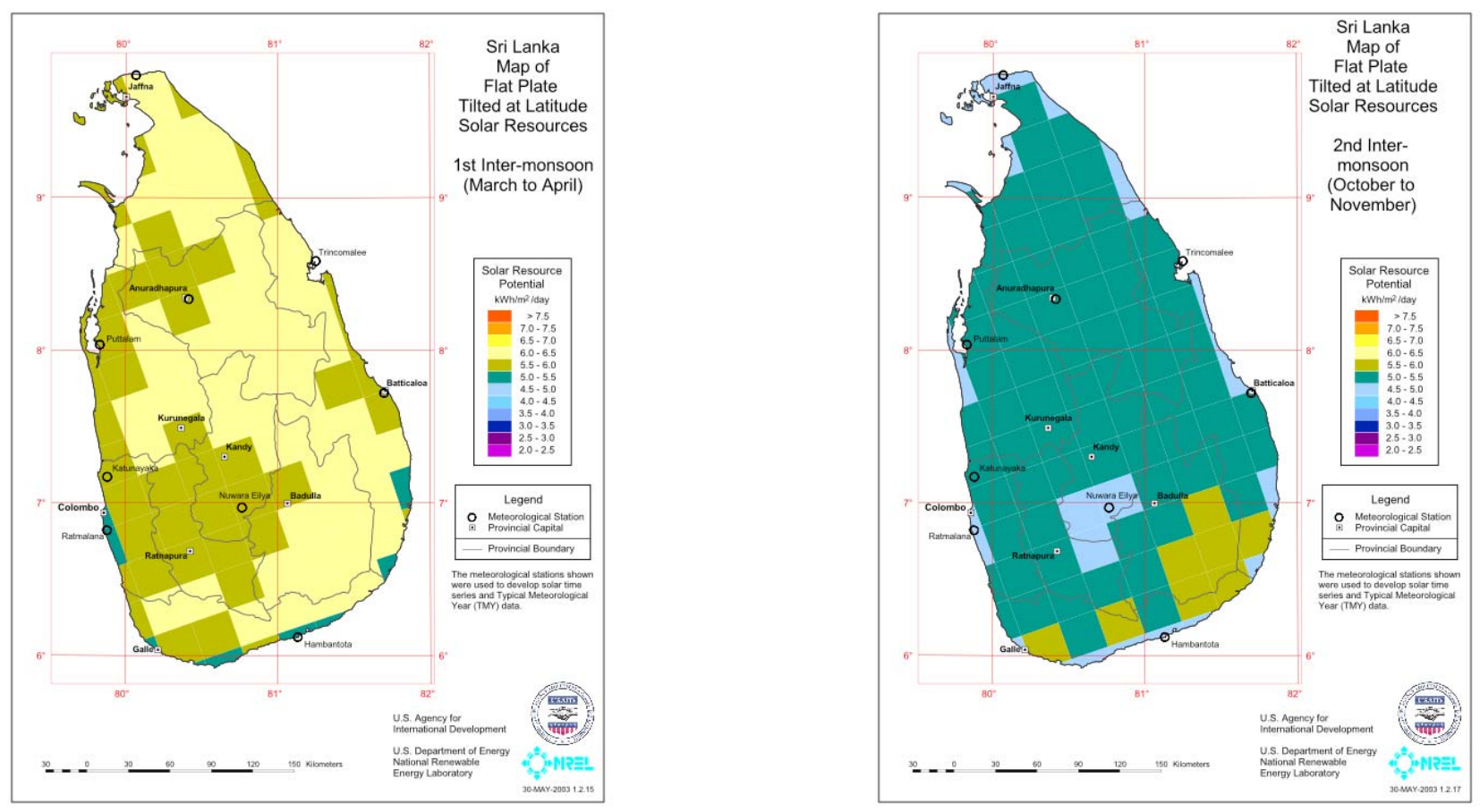

Figure 5:

Solar resources on a fixed flat-plate collector oriented south at latitude tilt for the two inter-Monsoonal periods: March-April (left) and October-November (right). 

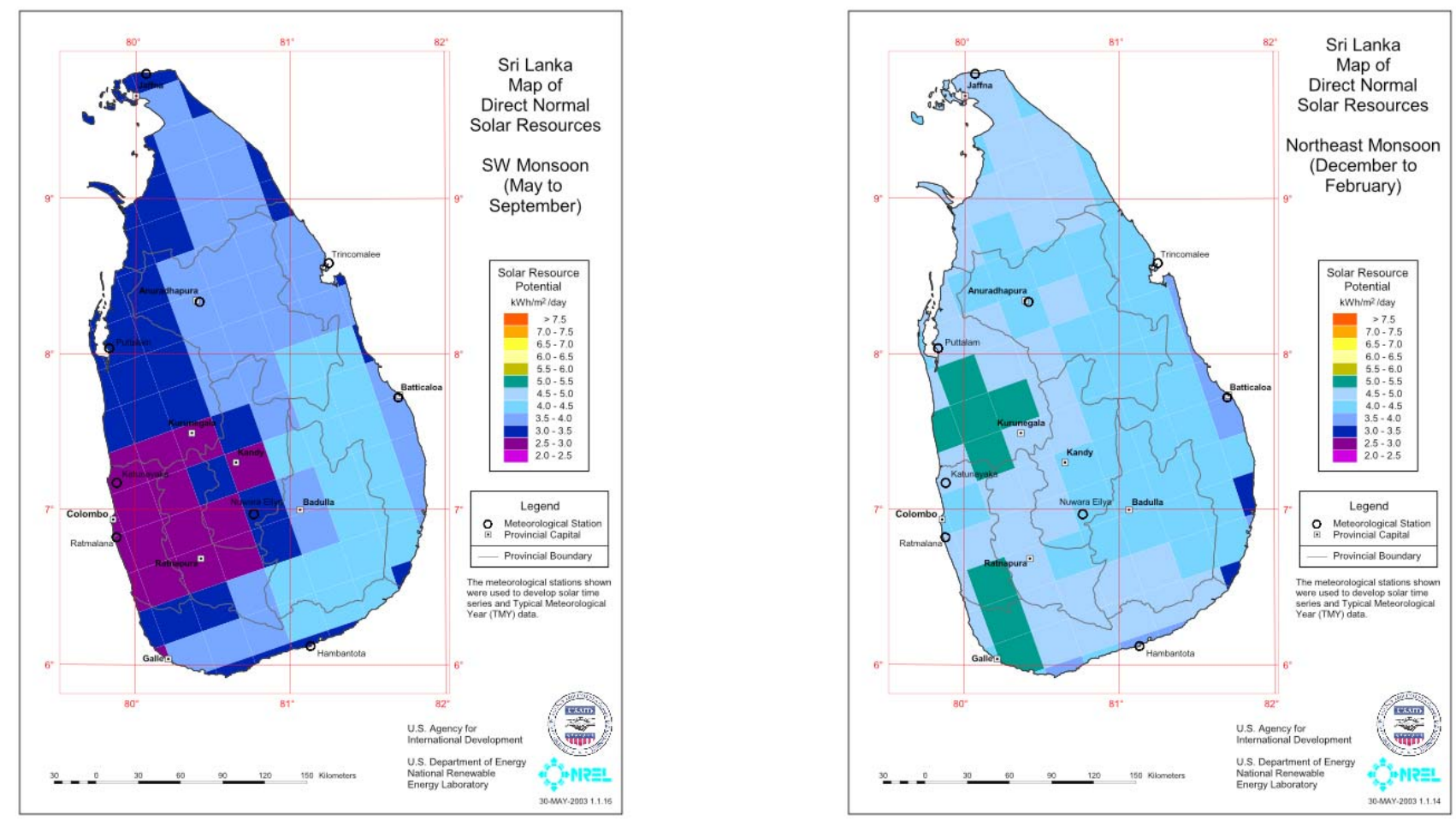

Figure 6:

DNI solar resources for the Southwest Monsoon (left) and the Northeast Monsoon (right).
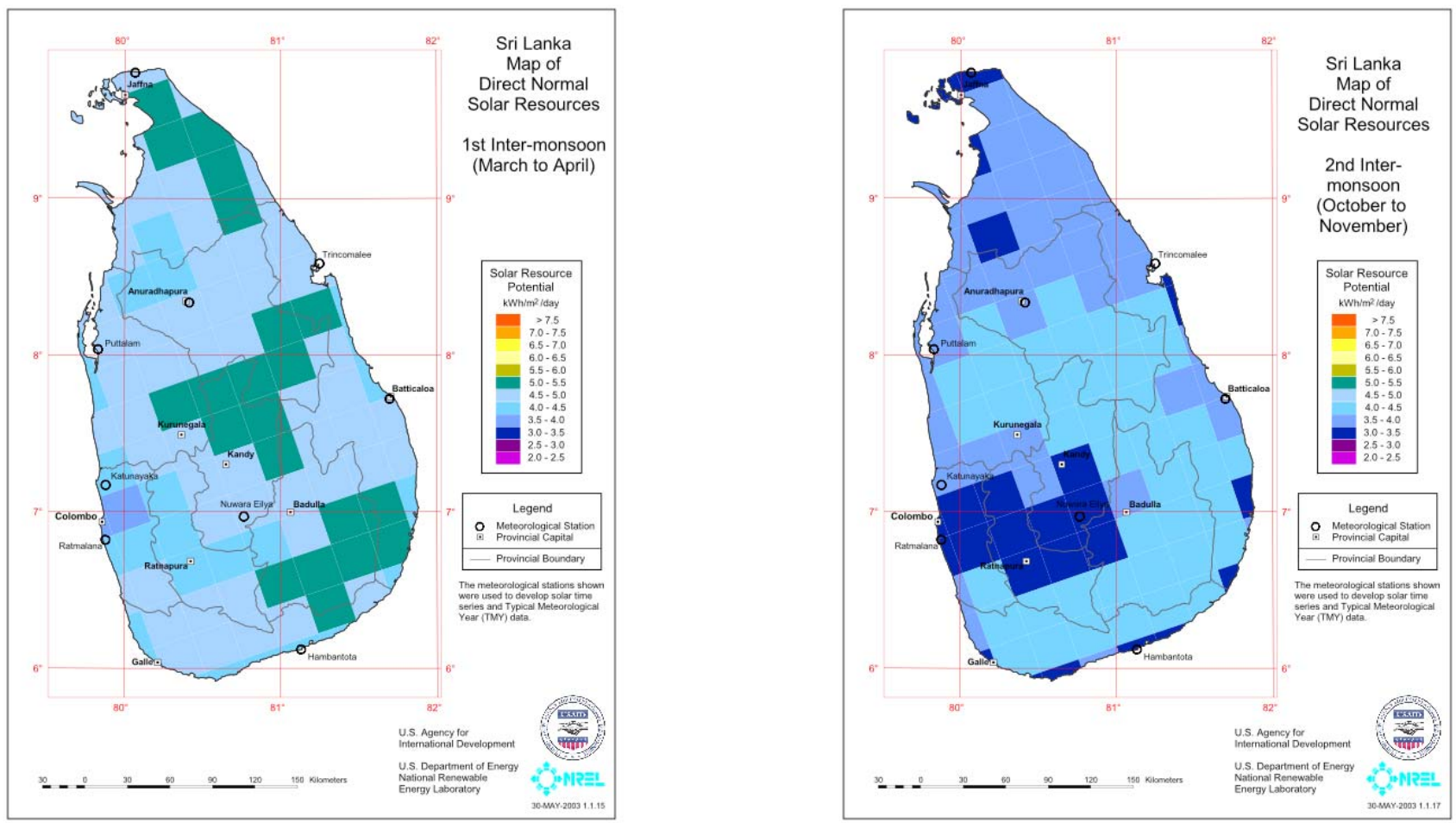

Figure 7:

DNI solar resources for the two inter-Monsoonal periods: March-April (left) and October-November (right). 


\section{Maldives Solar Climate}

Figure 8 shows the distribution of annual solar resources for a fixed collector oriented at latitude tilt and for DNI (e.g. 2-axis concentrating collectors) in the Maldives.

The CSR model provides monthly average daily total solar radiation estimates for the seven-year period 1985-1991. The seasonal climate is depicted for four major regimes: the Northeast Monsoon (December through February), the Southwest Monsoon (May through September), and two inter-Monsoonal periods (March through April and October through November). Figure 9 shows the solar resource for a fixed flat plate collector oriented at latitude tilt for the Northeast and the Southwest Monsoons in the Maldives, and Figure 10 shows the same solar resource value for the two inter-Monsoonal periods. Figure 11 shows the DNI resource for the Northeast and the Southwest monsoons, while Figure 12 shows the DNI resource for the two inter-monsoonal periods.
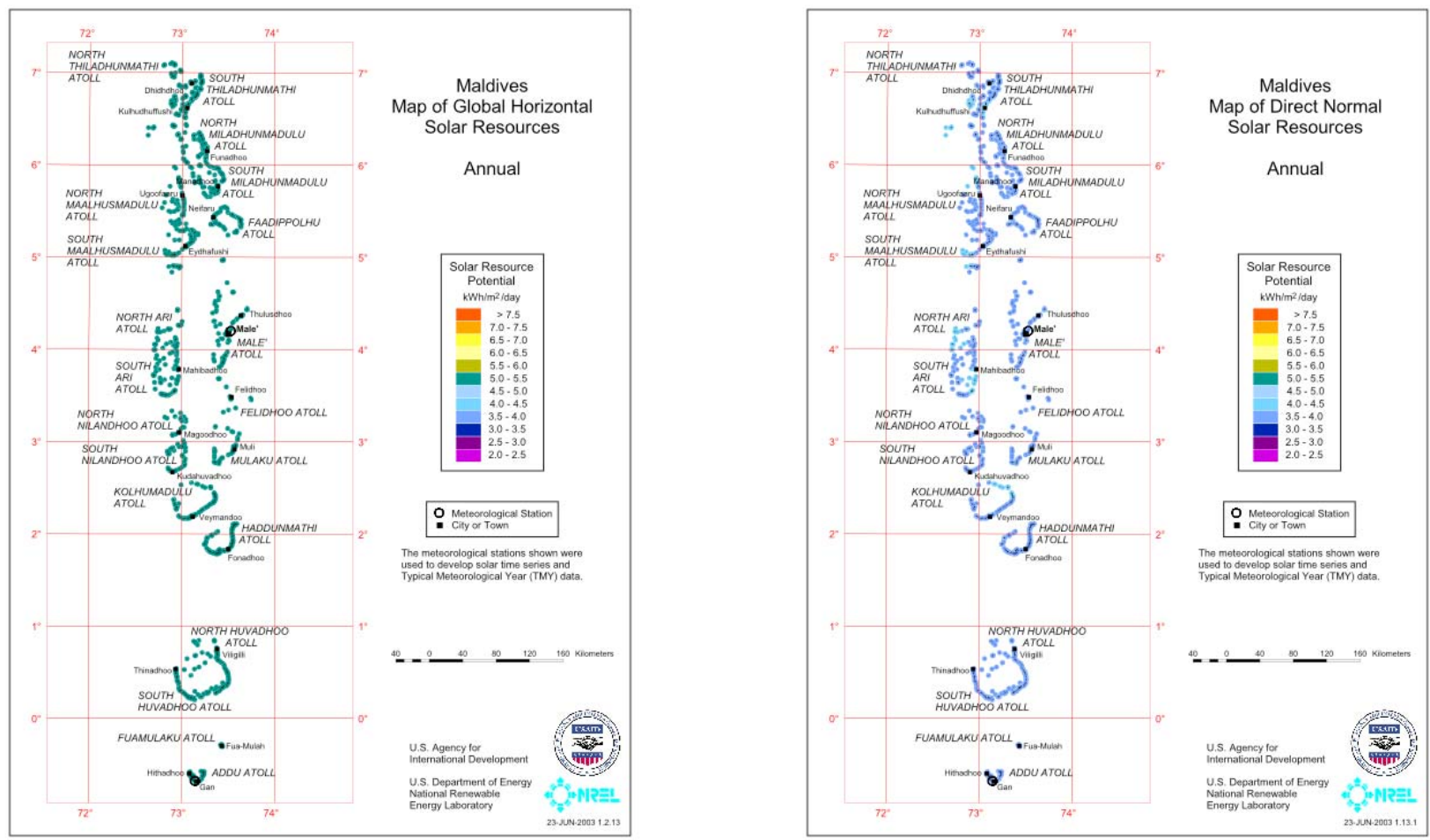

Figure 8:

Annual average daily total solar resources for fixed flat plate collector tilted at latitude (left) and DNI (right). 

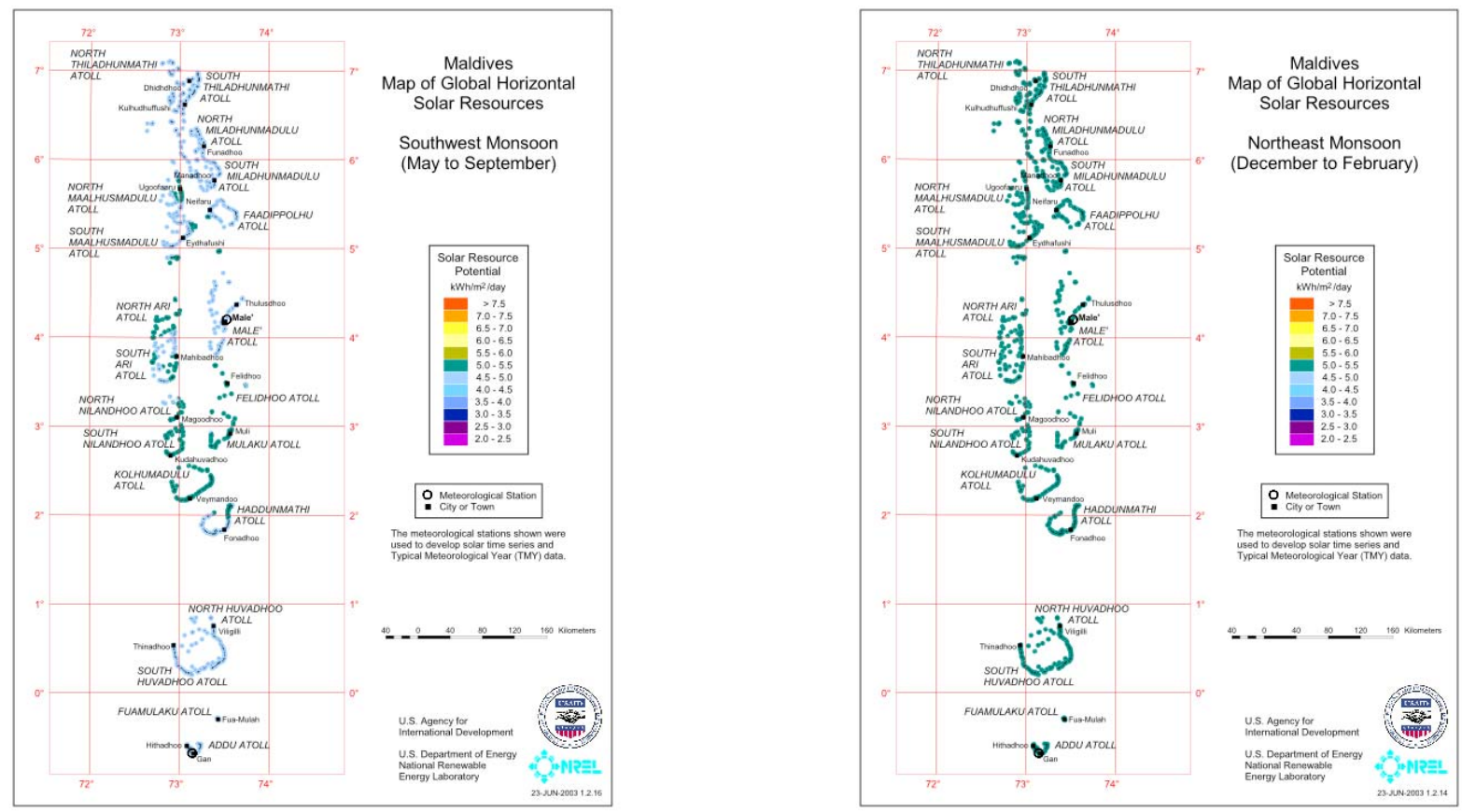

Figure 9:

Solar resources on a fixed flat-plate collector oriented at latitude tilt for the Southwest Monsoon (left) and the Northeast Monsoon (right).
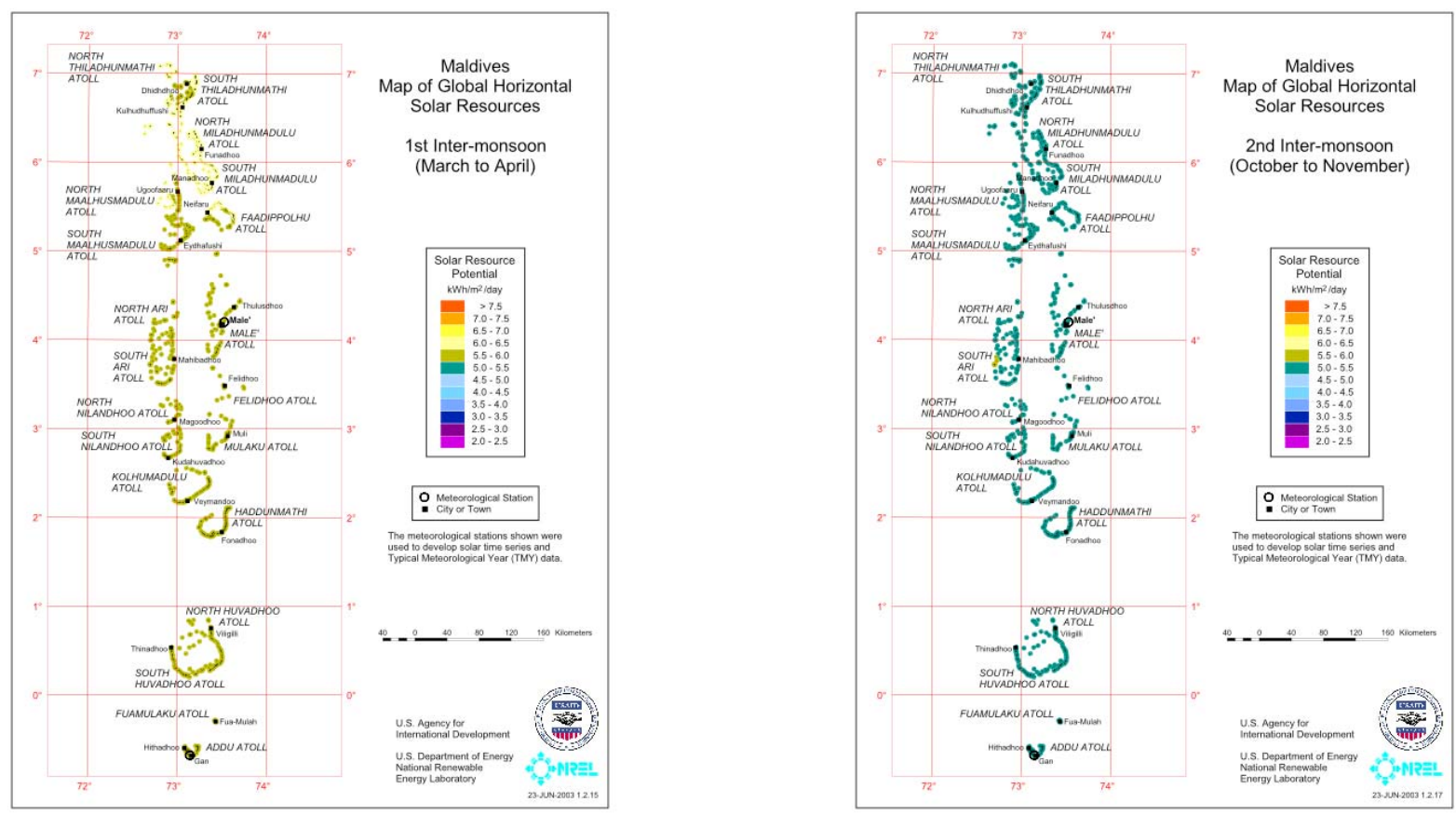

Figure 10:

Solar resources on a fixed flat-plate collector oriented south at latitude tilt for the two inter-Monsoonal periods: March-April (left) and October-November (right). 

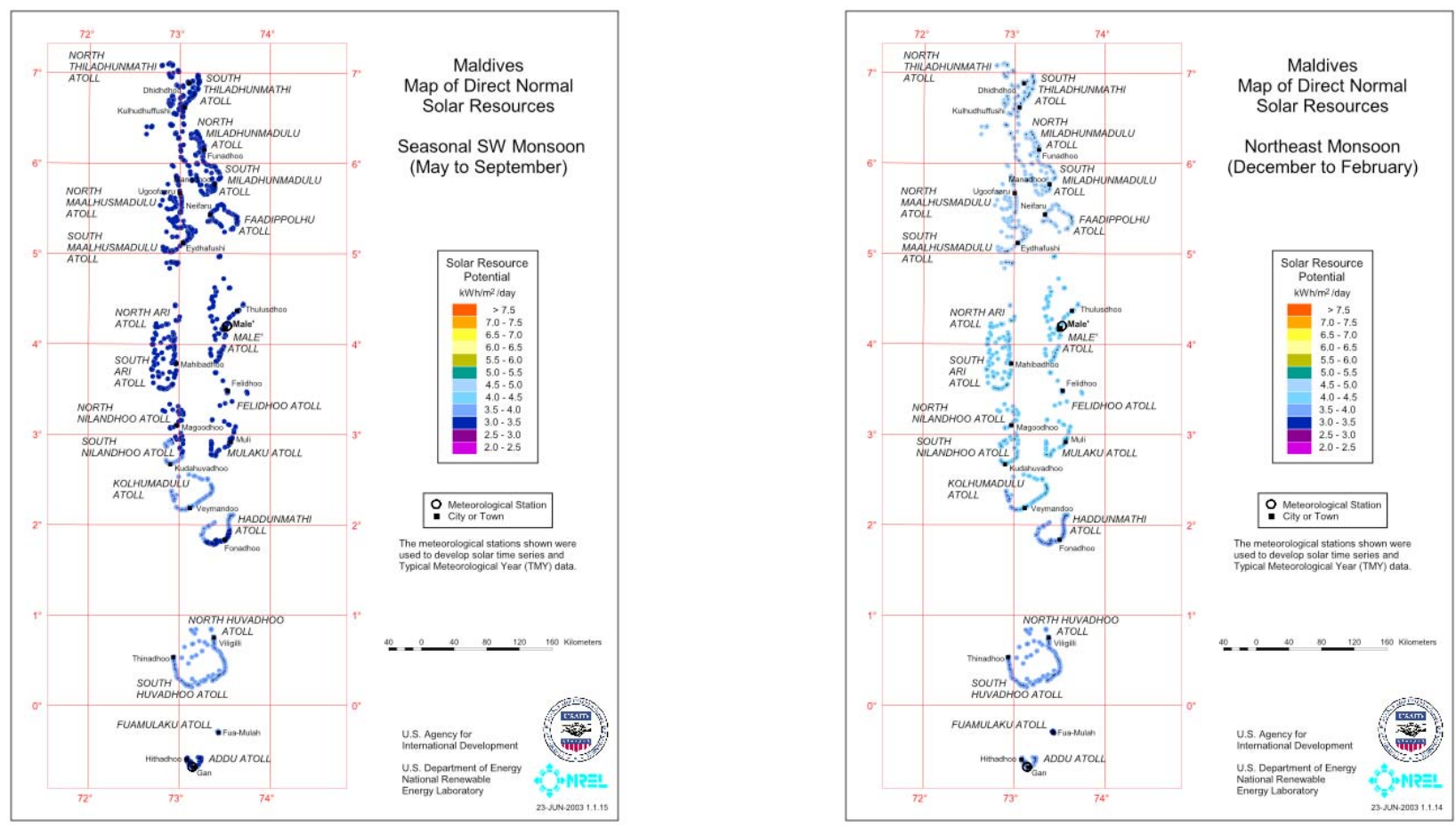

Figure 11:

DNI solar resources for the Southwest Monsoon (left) and the Northeast Monsoon (right).
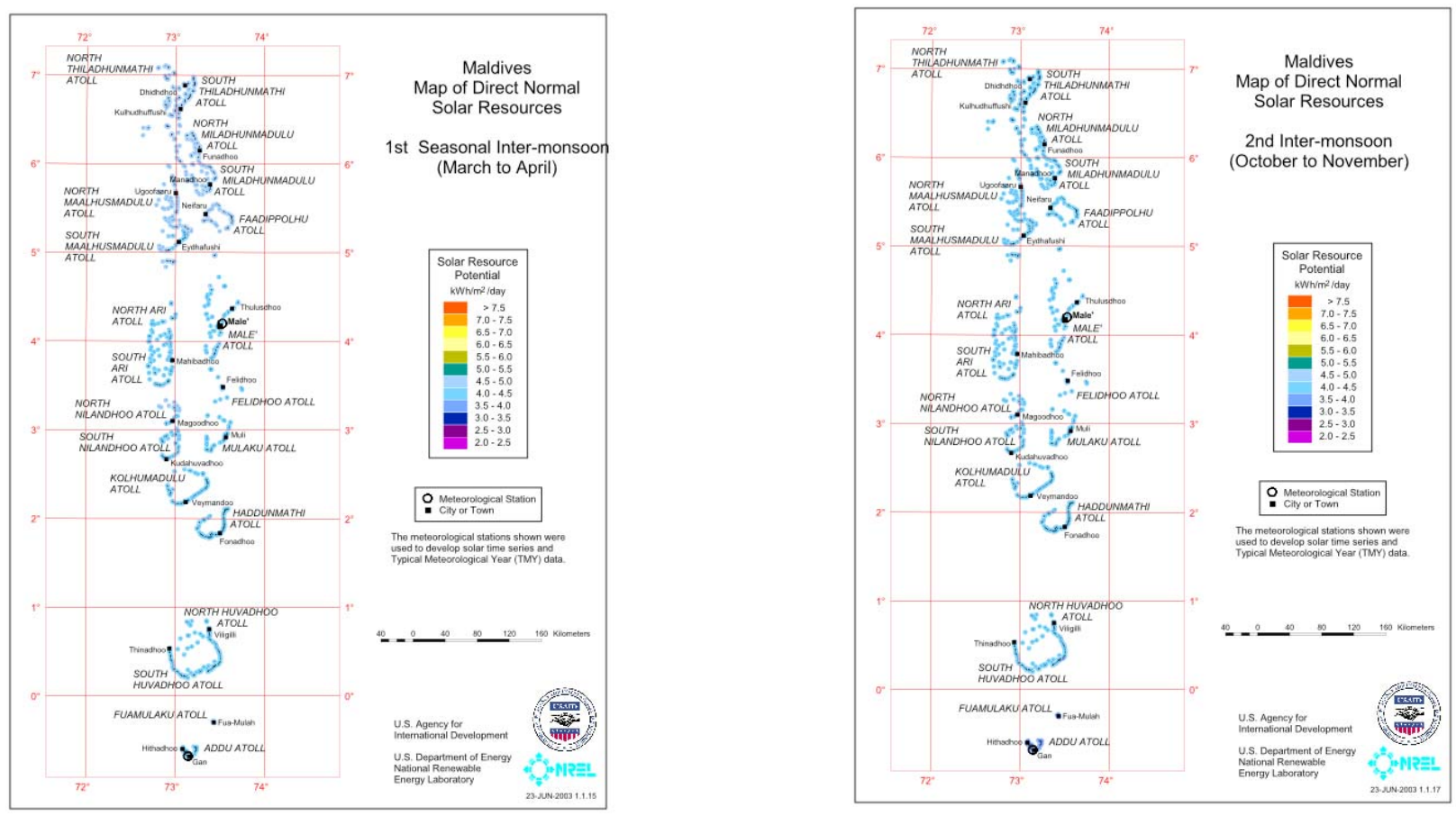

Figure 12:

DNI solar resources for the two inter-Monsoonal periods: March-April (left) and October-November (right). 


\section{Summary and Conclusions}

An assessment of the solar resources has been developed for Sri Lanka and the Maldives using a methodology that converts cloud cover information, derived either from surface observations or satellite imagery, into solar resource estimates. The annual results for Sri Lanka, which range from 4.5 to $6.0 \mathrm{kWh} / \mathrm{m}^{2} /$ day, are consistent with, and slightly higher than earlier studies using sunshine recorders, which gave results of 4.2 to $5.6 \mathrm{kWh} / \mathrm{m}^{2} /$ day. The slightly higher results are due most likely to the fact that, for Sri Lanka, we chose to calculate the resource for a flat plate collector tilted to latitude, rather than the more traditional method of calculating the resource on a horizontal surface that the earlier studies used. The patterns show similarities with the earlier results except near coastal areas, where the new analyses show lower solar resources than those from sunshine recorders. We believe that this is due to potential errors in over-water cloud cover values derived from satellite imagery, which would result in lower solar resource values for those cells along the coastlines that are predominantly over water.

The study shows that ample resources exist throughout the year for virtually all locations in Sri Lanka and the Maldives for PV applications, such as solar home systems and remote power applications. In the Maldives in particular, the high levels of solar resource throughout the entire country make it well suited for off-grid, island-based photovoltaic applications as an alternate to, or supplement to, diesel power generators. Because of the general high level of cloudiness and humidity associated with tropical settings such as this, the resources for concentrating solar power are generally less than adequate, except for certain times of the year.

The variability in global horizontal solar resources is relatively small across most of the country of Sri Lanka, despite the impact of terrain characteristics on cloud formation. The resource generally varies spatially at most $20 \%$ to $30 \%$ during any given season. The highest resources are in the northern and southern regions, and the lowest resources are in the interior hill country. The variability in resources across the Maldives is even smaller, since there is virtually no terrain effect in this country.

The seasonal variations in solar resources in Sri Lanka can be somewhat greater at specific locations, for example ranging from 4.5 to $6.5 \mathrm{kWh} / \mathrm{m}^{2} /$ day in the hill country, and the effects of the changing directions in wind flow and storm patterns between the southwest and the northeast monsoons are quite sharp. During the southwest monsoon, with airflow generally from the southwest to the northeast, the lee side of the mountains (the northeast portion of the country) shows quite high solar resources. During the northeast monsoon, the southern and western portions of the country show higher resources. However, the highest resources occur during the hot dry period from March and April when the transition between the northeast and the southwest monsoon occurs.

The seasonal variability in the Maldives is also larger than the spatial variability across the country at any given time, but less dramatic. Again, the period of highest solar resource is in March and April, when the region is transitioning from the northeast to the southwest monsoon. 


\section{Acknowledgements}

The authors wish to thank the many individuals and organizations in Sri Lanka and the Republic of the Maldives for the assistance they received throughout this study. In particular we wish to thank:

Cynthia Lowry, USAID/Washington, DC

Upali Daranagama, USAID/Sri Lanka

Bob Beckman and Kavita Sinha, USAID/Delhi

Ariyadasa Leklamlage and A. M. A. Alwis, Ceylon Electricty Board/Sri Lanka

Michael A. Warnakulasoorlya, Ministry of Power and Energy, Sri Lanka

Sunith Fernando, Resource Management Associates, Sri Lanka

G.H.P. Dharmaratna, Department of Meteorology, Sri Lanka

Abdul Razzak Idris and Abdul Shaheed, Ministry of Communication, Science, and Technology, Republic of the Maldives

Abdul Shakoor, State Electric Company, Republic of the Maldives

Ali Shareef,, National Meteorological Center, Republic of the Maldives

\section{References}

[1] Samuel, T. D. M. A., (1991): Estimation of Global Radiation for Sri Lanka. Solar Energy 47(5):333-337.

[2] Samuel, T. D. M. A., and R. Srikauthan (1982): Solar Radiation Estimation for Sri Lanka. Transactions of the Institution of Engineering, Sri Lanka, pp. 15-19.

[3] Maxwell E.L. (1998) METSTAT-The solar radiation model used in the production of the NSRDB. Solar Energy 62, 4, 263-279.

[4] Squires M.F. (1995) The demographics of worldwide weather data. ASHRAE Transactions. Vol. 1, Part 1, pp. 470-475.

[5] Plantico M.S. and Lott J.N. (1995) Foreign weather data servicing at NCDC. ASHRAE Transactions. Vol. 1, Part 1, pp. 484-490.

[6] Collins, W.D. et al., Simulating aerosols using a chemical transport model with assimilation of satellite aerosol retrievals: Methodology for INDOEX. J. Geophys. Res., 106D, 7313-7336, 2001.

[7] Collins W.D. et al., Simulation of aerosol distributions and radiative forcing for INDOEX: Regional climate impacts. J. Geophys. Res., 107D, 8028, doi:10.1029/2000JD000032, 2002 . 


\section{References Continued}

[8] Li F. and Ramanathan V., Winter to summer monsoon variation of aerosol optical depth over the tropical Indian Ocean. J. Geophys. Res., 107D, doi:10.1029/2001JD000949, 2002.

[9] Tahnk W.R. and Coakley J.A., Aerosol optical depth and direct radiative forcing for INDOEX derived from AVHRR: Observations, January-March 1996-2000. J. Geophys. Res., 107D, doi: 10.1029/2000JD000183, 2002.

[10] Holben, B. N., Eck, T.F., and Slutsker, I. (1998): AERONET-A federated instrument network and data archive for aerosol characterization. Rem. Sensing Environ., 66:1-16. http://aeronoet.gsfc.nasa.gov.

[11] Husar, R. B., J. M. Prospero and L. L. Stowe, Characterization of Tropospheric aerosols over the oceans with the NOAA advanced very high resolution radiometer optical thickness operational product, J. Geophys. Res., 102, 16,889-16,909, 1997.

[12] Gueymard, C., 2003: Aerosol Data for the Maldives. Consultant Report to the National Renewable Energy Laboratory.

[13] Randel, David L., Thomas H. Vonder Haar, Mark A. Ringerud, Graeme L. Stephens, Thomas J. Greenwald, and Cynthia L. Combs (1996): A New Global Water Vapor Dataset. Bull. Amer. Meteor. Soc. 77(6):1233-1246.

[14] Global Relief CD-ROM: NOAA/NESDIS, Marine Geology and Geophysics Division, Boulder, $\mathrm{CO}$

[15] Guimaraes, P. and McPeters, R., TOMS Gridded Ozone Data (1978-1988), CD-ROM, Goddard Space Flight Center, NASA, Greenbelt, MD, 1990

[16] Li Z., Garand L. Estimation of Surface Albedo from Space: a Parameterization for Global Application; Journal of Geophysical Research, 1994, Vol. 99, pp. 8335-8350

[17] Marion W. and George R. (2001) Calculation of solar radiation using a methodology with worldwide potential. Solar Energy 71, 4, 275-283.

[18] Marion W. and Urban K. (1995) User's manual for TMY2s-typical meteorological years derived from the 1961-1990 National Solar Radiation Data Base. NREL/SP-463-7668. National Renewable Energy Laboratory, Golden, CO. 


\section{REPORT DOCUMENTATION PAGE}

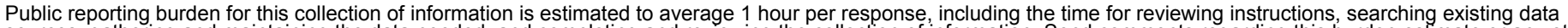

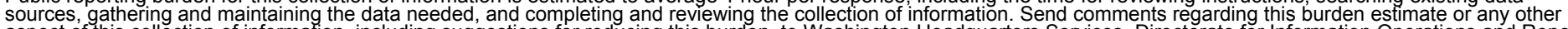

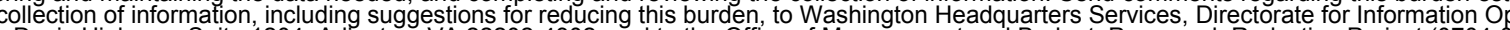

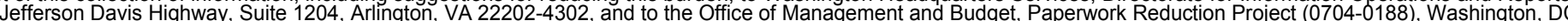
20503

\begin{tabular}{|l|l|l}
\hline 1. AGENCY USE ONLY (Leave blank) & $\begin{array}{c}\text { 2. REPORT DATE } \\
\text { August } 2003\end{array}$ & $\begin{array}{l}\text { 3. REPORT TYPE AND DATES COVERED } \\
\text { Technical report }\end{array}$ \\
\hline
\end{tabular}

4. TITLE AND SUBTITLE

August 2003

5. FUNDING NUMBERS

Solar Resource Assessment for Sri Lanka and Maldives

WF7C.2000

6. $\operatorname{AUTHOR}(\mathrm{S})$

D. Renné; R. George; B. Marion; D. Heimiller; C. Gueymard

7. PERFORMING ORGANIZATION NAME(S) AND ADDRESS(ES)

National Renewable Energy Laboratory

1617 Cole Blvd.

8. PERFORIMING ORGANIZATION REPORT NUMBER

Golden, CO 80401-3393

NREL/TP-710-34645

9. SPONSORING/MONITORING AGENCY NAME(S) AND ADDRESS(ES)

10. SPONSORING/MONITORING AGENCY REPORT NUMBER

11. SUPPLEMENTARY NOTES

12a. DISTRIBUTION/AVAILABILITY STATEMENT

National Technical Information Service

12b. DISTRIBUTION CODE

U.S. Department of Commerce

5285 Port Royal Road

Springfield, VA 22161

13. ABSTRACT (Maximum 200 words)

The extent of solar resources in Sri Lanka has been estimated in the past based on a study of the daily total direct sunshine hours recorded at a number of weather and agricultural stations throughout the country. The studies do not include the other solar resource components (Direct Normal Irradiance, or DNI, and diffuse radiation) that are required for other types of solar applications, such as concentrating solar power and building daylighting. This study is an effort to improve on these estimates in two ways: 1) to apply a gridded cloud cover database at a 40-km resolution to produce updated monthly average daily total estimates of all solar resources (global horizontal, DNI, and diffuse) for the country, and 2) to input hourly or three-hourly cloud cover observations made at nine weather stations in Sri Lanka and two in the Maldives into a solar model that produces estimates of hourly solar radiation values of the direct normal, global, and diffuse resource covering the length of the observational period. Details and results of these studies are summarized in this report.

14. SUBJECT TERMS

solar resource assessment; Sri Lanka; Maldives; estimation techniques; solar energy; electrical loads; electricity; direct normal; global horizontal radiation; DNI; diffuse; climatological solar radiation; photovoltaics

17. SECURITY CLASSIFICATION OF REPORT

Unclassified
18. SECURITY CLASSIFICATION OF THIS PAGE Unclassified
19. SECURITY CLASSIFICATION OF ABSTRACT Unclassified
15. NUMBER OF PAGES

16. PRICE CODE

20. LIMITATION OF ABSTRACT

UL 


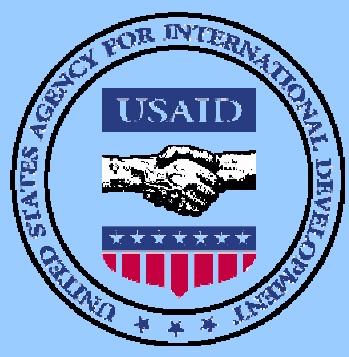

U.S. Agency for International Development

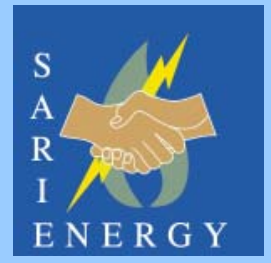

South Asia Regional Initiative for Energy Cooperation and Development (SARI/Energy)

Ceylon Electricity Board, Sri Lanka

Ministry of Communication, Science, and Technology, Republic of Maldives

\section{Prepared by}

National Renewable Energy Laboratory 1617 Cole Boulevard • Golden, Colorado 80401-3393

A national laboratory of the U.S. Department of Energy

Managed by Midwest Research Institute $\bullet$ Battelle $\bullet$ Bechtel for the U.S. Department of Energy under Contract No. DE-AC36-99-G010337 NREL/TP-710-34645 • August 2003 